Article

\title{
Assessment of Critical Diffusion Factors of Public-Private Partnership and Social Policy: Evidence from Mainland Prefecture-Level Cities in China
}

\author{
Xiaohan Li ${ }^{1}$ (D), Yang $\mathrm{Lv}^{2}$, Md Nazirul Islam Sarker ${ }^{3, *}$ and Xun Zeng ${ }^{4}$ \\ School of Public Administration, Sichuan University, Chengdu 610065, China; lixiaohan@stu.scu.edu.cn \\ College of Teachers, Chengdu University, Chengdu 610106, China; lvyang@cdu.edu.cn \\ School of Political Science and Public Administration, Neijiang Normal University, Neijiang 641112, China \\ 4 School of Management, Sichuan University of Science and Engineering, Zigong 643000, China; \\ zengxun@suse.edu.cn \\ * Correspondence: sarker@njtc.edu.cn
}

Citation: Li, X.; Lv, Y.; Sarker, M.N.I.; Zeng, X. Assessment of Critical Diffusion Factors of Public-Private Partnership and Social Policy:

Evidence from Mainland Prefecture-Level Cities in China. Land 2022, 11, 335. https://doi.org/ $10.3390 /$ land11030335

Academic Editor: Thomas Maloutas

Received: 13 February 2022

Accepted: 23 February 2022

Published: 24 February 2022

Publisher's Note: MDPI stays neutral with regard to jurisdictional claims in published maps and institutional affiliations.

Copyright: (C) 2022 by the authors. Licensee MDPI, Basel, Switzerland. This article is an open access article distributed under the terms and conditions of the Creative Commons Attribution (CC BY) license (https:// creativecommons.org/licenses/by/ $4.0 /)$.

\begin{abstract}
Cooperation between government and social capital is an important starting point in the supply-side reform of public services. It is also an effective practice in public governance innovation. Based on policy diffusion theory and event history analysis (EHA), this study analyzes panel data from 282 mainland prefecture-level cities in China from 2004-2020 to explore public-private partnerships' critical diffusion factors. The study reveals that motivation factors, resource/obstacle factors, and external factors affect government and social capital cooperation policies to different extents. The main driving forces for local governments to adopt these policies are population size, level of economic development, government financial resources, the learning mechanism, and the imitation mechanism. This study proposes the following arguments: firstly, that the ultimate goal of policy innovation is to solve social contradictions and meet public demand; secondly, that economic resources can help to adopt policy innovation and proper diffusion; thirdly, that the public-private partnership (PPP) model has been continuously developed by using experience from other projects or cities through a learning mechanism; and finally, that policy publicity and public opinion expressed via the mainstream media are not only an inducement for policy innovation and diffusion, but also a powerful guarantee. The experience of local governments in China can help to verify whether the "positive factors" that are traditionally considered to be conducive to the cooperation between the government and social capital are effective, and to reveal the internal logic of the innovation diffusion of public policies of local governments in China from a more multidimensional perspective.
\end{abstract}

Keywords: political landscape; land use; land reform; public services; diffusion of policy innovations; event history analysis

\section{Introduction}

The public-private partnership (PPP) is an important tool to improve the supply efficiency and service quality of public services, and it is also a key through which to accelerate the transformation of government functions and enhance the capacity of national governance [1]. Under the current pressures of economic downturn and COVID-19 pandemic prevention, the important role of infrastructure construction as the cornerstone of economic and social development is further highlighted. In China's 2020 State Council report on the work of the government, new infrastructure construction is listed as one of the key supporting projects of that year, having become an important measure for the impact of the economic downturn and the pandemic, thus providing the PPP model with new application space.

The PPP model is a partnership of "benefit sharing, risk sharing and whole process cooperation" formed from the logical starting point of the effective supply of public services 
and public products by the government and social capital [2]. This management model is not a new idea, but a special form under its unique background and historical trend [3]. In particular, PPPs and government franchises are based on different legal and discourse systems in different countries [4]. In a broad sense, the PPP is the successor developed from the government franchise system, while the government franchise is a specific method and measure of the PPP [5,6]. Management measures of infrastructure and public utility franchises clearly propose that the government franchise is a form of PPP. This study adopts the concept of cooperation between government and social capital in a broad sense and brings the relevant policy of government franchise into its scope.

Since the 1960s-1970s, a global upsurge has occurred in PPP model expansion. Compared to developed countries in Europe and the United States (US), China's PPP development has obtained central policy support with many PPP projects rapidly launched. By 2017, PPP development had achieved full coverage of 31 provincial administrative units in China. Statistics show that more than $90 \%$ of prefecture-level municipal governments had adopted this reform strategy by the end of 2020 (Figure 1). In the face of this explosive growth, imperfect contracts have led to hot policy and cold practice, deviation between policy objectives and local government behavior, frequent rent-seeking behavior, and other issues in China's PPPs, which are affecting the efficiency of PPP policy diffusion in its distributed exploration. Xufeng and Zhao [7] evaluated China's social innovation policy and found that when implementing a new social policy, city governments must balance the social desires of local citizens with fiscal constraints; at the same time, they are influenced by administrative orders from higher-level governments and the vertical fiscal relationships between governments at different levels, as well as competitive pressures from other cities at the same level.

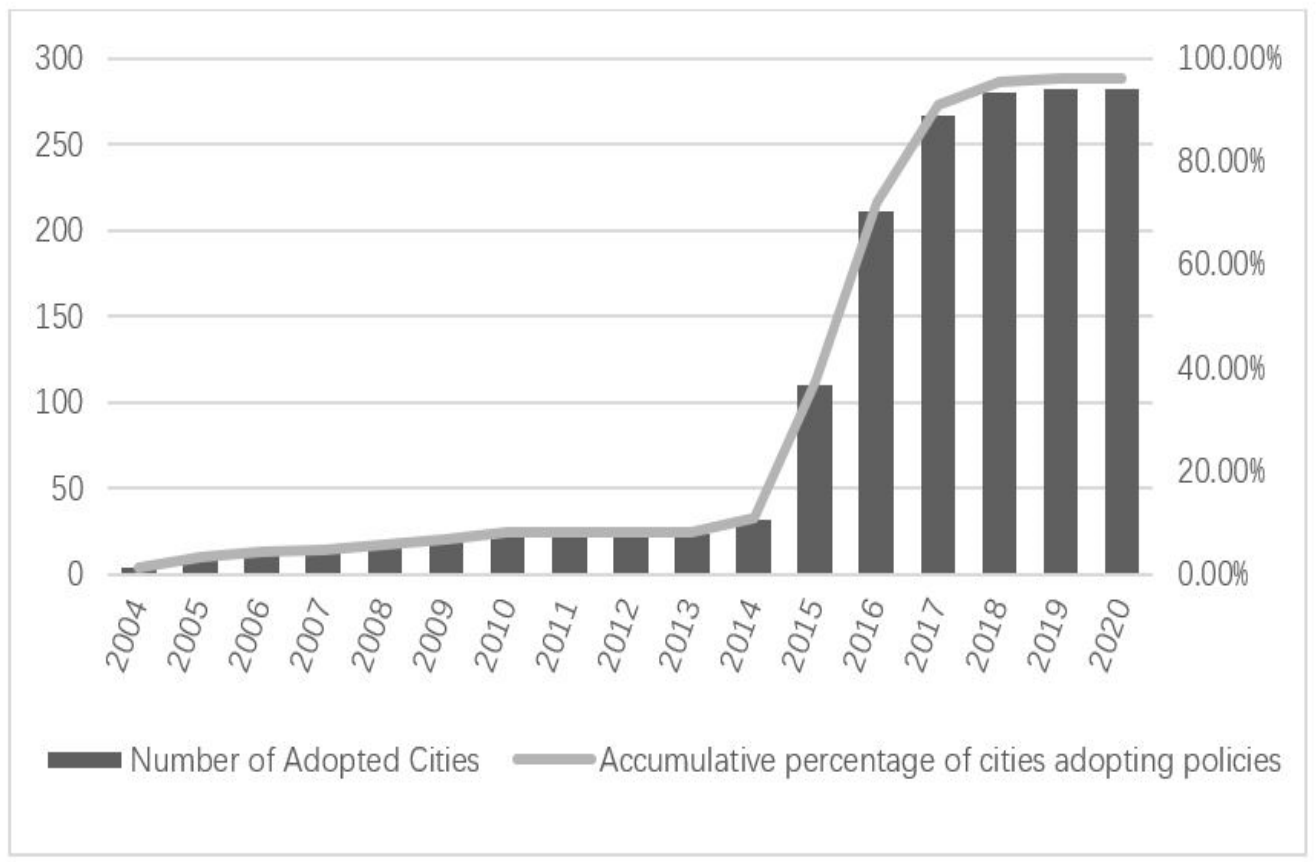

Figure 1. Diffusion of PPP policy in prefecture-level cities in China.

At present, academic discussion on PPP policy diffusion mainly focuses on the analysis of diffusion models [8,9], time-space characteristics [10], etc. Research on the causes of PPP policy diffusion focuses on discrimination [11,12] and importance ranking of influencing factors [2,13] and is rarely from the perspective of the combination of time series and space scale to interpret PPP policy diffusion in a holistic way [14]. In considering the related issues, this study addresses three key questions: How is the diffusion path of PPP policy to be followed by local governments? What factors affect the diffusion of PPP policy between local governments? How can the efficiency and quality of policy adoption be 
improved? Therefore, this study seeks to provide coherent answers to these three questions by combining event history analysis (EHA) with policy diffusion theory.

\section{Theoretical Framework and Research Hypotheses}

\subsection{Theoretical Framework}

Research on the diffusion of policy innovation began in the 1960s. The study on the diffusion of innovation between US states by Professor Walker of the University of Michigan formed the prelude to research in this field [15]. In the following years, efforts by Frances Stokes Berry and William D. Berry [16], Virginia Gray [17], Paul Sabatier and Lawrence B. Mohr [18], Rogers [19], and other scholars [3,20,21] led to beneficial attempts in the fields of management, politics, sociology, and other disciplines. These studies further enriched and developed the theoretical grounds of policy innovation and expansion and the contribution to public policy research.

Policy diffusion is a structural process, a regional model of imitation, and a learning and reference method based on competitive advantage [19]. Rogers believed that innovation, time, communication channels, and the social system are the four elements of policy innovation diffusion [19]. Through this process, policy innovation spreads and is adopted among government, organizational, and other social systems over a certain period of time through specific channels of communication [19]. At present, based on theoretical research and empirical testing, scholars have summarized the internal and external factors that affect policy innovation diffusion [22] as including political factors [23], economic resources [24], and social development factors [20], as well as factors such as leader factors, conformity factors, competition factors, and information channel factors [25]. After their in-depth analysis of the influencing factors of policy diffusion, Berry and Berry [16] proposed the internal decision model and communication model of policy diffusion analysis, integrating the two models to form a general model of state government innovation [21] in the following form:

$$
\begin{gathered}
\text { Adoption possibilities } i_{i, t}=f\left(\text { motivation }_{i, t},{\text { resources } / \text { obstacles }_{i, t},}\right. \\
\text { other } \left.\text { policies }_{i, t} \text {, external factors }{ }_{i, t}\right) .
\end{gathered}
$$

where adoption possibilities $s_{i, t}$ is the adoption probability that state government $i$ adopts the PPP policy at time $t$. Rogers' diffusion of innovation (DOI) model emphasized that policy innovation diffusion is influenced by three factors: the leader's personal characteristics, the organization's internal characteristics, and the external environment [19]. Wejnert proposed a comprehensive analysis framework which summarizes three types of variables: the characteristics of the innovation itself, the characteristics of actors that affect policy adoption, and the characteristics of the environment [26]. Shipan and Volden [27] summarized four mechanisms of policy innovation and diffusion, namely the compulsory mechanism, the competitive mechanism, the learning mechanism, and the imitation mechanism. To be specific, the compulsory mechanism refers to the direct or indirect compulsory requirements of the higher level of government which is reflected in top-down institutional pressure [28]. The competitive mechanism pays attention to intergovernmental competition, especially policy adoption by neighboring governments [29]. The learning mechanism refers to the direction of regions where policies have been adopted [9]. The imitation mechanism is embodied in the process of socialized communication, reflecting a type of conformity effect, such as a "policy clone" [27]. Based on the classical analysis framework of policy diffusion research combined with China's national conditions, this study constructs an analysis framework of the policy diffusion of cooperation between local governments and social capital on China's mainland. The study examines the impact of three kinds of variables on policy diffusion, namely motivation factors, resource/obstacle factors, and external factors. A larger population scale presents motivational factors. Resource and obstacle factors comprise higher economic development, sufficient financial resources, and higher administrative levels. Similarly, external factors comprise interruption of higher authorities, government and social cooperation, a higher proportion of cities adopting policy innovation, and news reports about cooperation policy. 
Figure 2 portrays the relationships between the various factors and the hypotheses for achieving the exact status of cooperation between government and social capital and policy innovation.

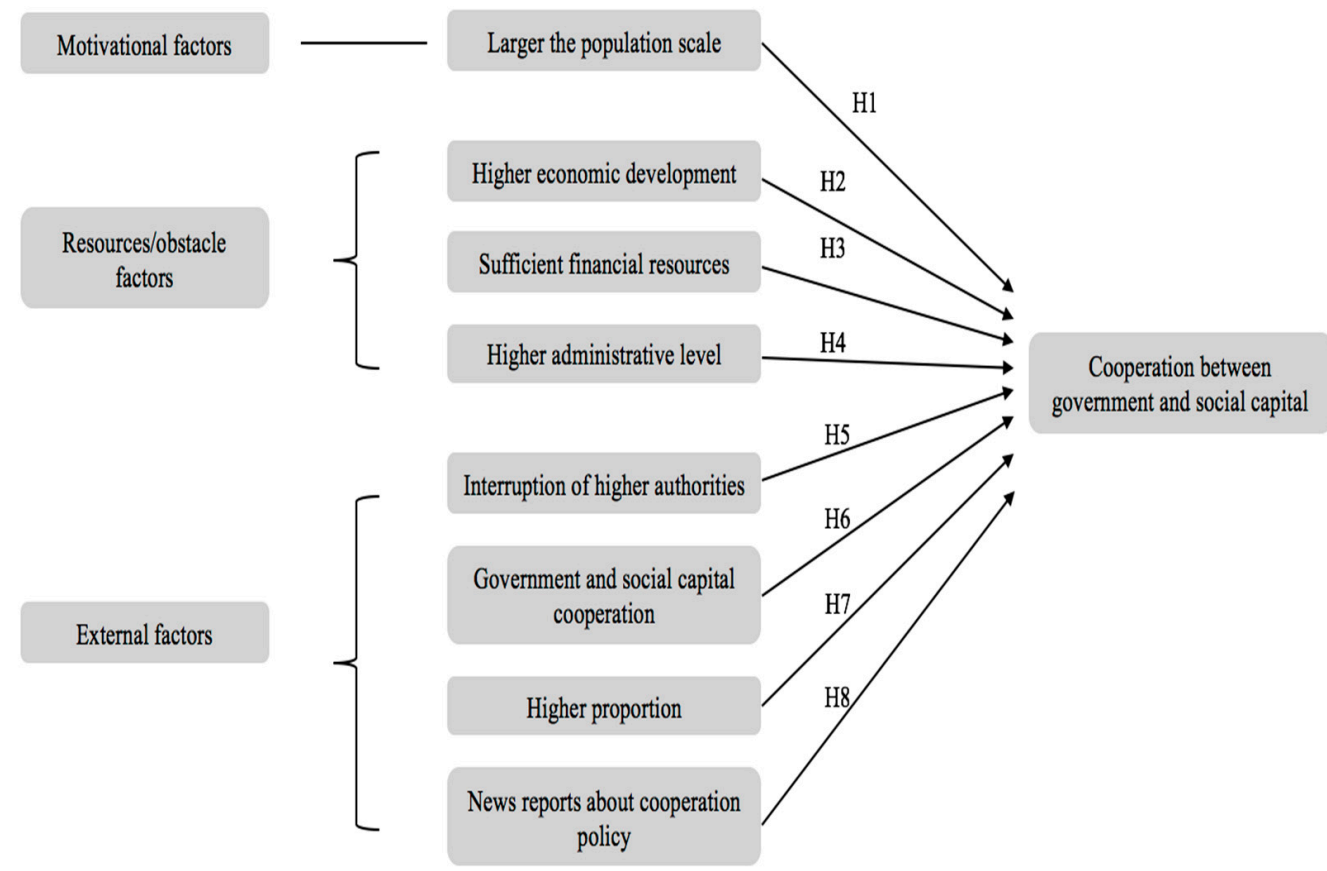

Figure 2. Conceptual framework of the study.

\subsection{Hypothesis Development}

\subsubsection{Motivational Factor}

An active response to public demand is the driving force for policy innovation [15]. According to David Easton's political system theory [30], a good public policy is the government's effective response to public demand, with this being the logical starting point of government decision making and the ultimate concern of public policy innovation. Population size is a prerequisite for the size of public service demand along with supporting effective implementation of government decisions and effective use of public services [10]. Many studies have shown that population size is positively correlated with policy innovation adoption $[18,20,31]$. In cities or regions with large populations, public problems and social contradictions are more complex, the expression of public demand is relatively diverse, and the desire for policy innovation is higher. At the same time, the government is more likely to adopt innovative policies [7,32].

Hypothesis 1 (H1). The larger the population scale of a prefecture-level city is, the more likely it is to adopt the public-private partnership (PPP) policy.

\subsubsection{Resources/Obstacle Factors}

The level of economic development is the decisive factor in the government's adoption of innovation. In developed regions, the tolerance for policy innovation is stronger, the attitude to new policies is more open, and the economic pressure brought by policy innovation can be borne at the same time. Thus, the tendency of the government to adopt innovation is higher [33]. Gross domestic product (GDP) per capita, as the primary indicator reflecting the level of regional economic development, is found to be positively related to the government's adoption of innovation [1]. In cities with a high level of economic development, the higher the level of development by the private sector and enterprises, the stronger the vitality of policy participation [9], thus providing a strong basis for cooperation between the government and social capital. 
Hypothesis 2 (H2). The higher the level of economic development of a prefecture-level city is, the more likely it is to adopt the public-private partnership (PPP) policy.

The government's adoption of innovation policy needs rich financial resources, with many studies showing that local governments with such resources are more inclined to adopt innovation $[12,27]$. The government and social capital cooperation model involves signed contracts based on the principle of equal partnership [29]. The government gives consideration to social capital according to public service performance evaluation results $[34,35]$. In this model, abundant financial resources are the premise for cooperation between local governments and social capital and are important material guarantees for sustainable operation $[31,35]$. The more powerful the government's financial capability, the more qualified it is to adopt innovation policy [1].

Hypothesis 3 (H3). The richer the financial resources of a prefecture-level city are, the more likely it is to adopt the public-private partnership (PPP) policy.

The administrative level of cities is an important political factor for local governments in adopting innovation [7]. Under China's administrative framework, the higher the administrative level, the more autonomy the city has, the greater its political, economic, and social resources, and the more sufficient its resources for supporting the adoption of innovation policies. Findings from several studies [7,36-38], have shown that the city's administrative level has an important impact on its resource allocation ability and administrative authority: cities with a higher administrative level are more willing to adopt policy innovation [38]. In addition, provincial capital cities and subprovincial cities have the function of promoting the development of surrounding cities, and their priority to adopt innovation policies is naturally endowed by their special administrative status [39].

Hypothesis 4 (H4). The higher the administrative level of a prefecture-level city is, the more likely it is to adopt the public-private partnership (PPP) policy.

\subsubsection{External Factors}

According to the diffusion mechanism of policy innovation, as proposed by Shipan and Volden [26], the external factors affecting the policy innovation of government and social capital cooperation are as follows: pressure from higher authorities (compulsory mechanism), proximity effect (competition mechanism), proportion of cities in China that have adopted policy innovation (learning mechanism), and number of news reports (imitation mechanism).

According to vertical influence models, the central government is the pioneer of policy innovation and the model for local government [16]. The initiative and policy support of the higher-level of government is an important political factor that affects the local government's adoption of innovation. In the "pressure system" process and top-down authorization, the administrative behavior of the lower-level government is controlled by the pressure of the higher-level government [37]. From the perspective of risk avoidance, the local government needs to keep the same attitude as that of the central government [40]. Many studies have shown that when a policy innovation is recognized and supported by the higher-level government, local governments will be more active in the policy diffusion process [32,38].

Hypothesis 5 (H5). The greater the pressure exerted by higher-level authorities is, the more likely a prefecture-level city is to adopt the public-private partnership (PPP) policy.

The regional diffusion model assumes that the adoption of innovation by local governments is influenced by neighboring local governments, with the probability of policy innovation spreading in a certain region higher than that of national communication. The 
existing research has also shown that the diffusion of policy innovation in a region is affected by the adoption of policy innovation in neighboring regions [7]. In China, intergovernmental competition is presented in the form of a "political tournament". Local governments are affected by the operation logic of neighboring local governments and pay attention to their governance routes. Under this competition mechanism, the proximity effect of policy innovation occurs, leading to the spread of policy innovation in a certain region [14].

Hypothesis 6 (H6). The greater the level of implementation of government and social capital cooperation policies is in neighboring prefecture-level cities, the more likely a prefecture-level city is to adopt them.

Both the learning mechanism and the competition mechanism reflect the interaction between governments at the same level in the policy diffusion process. Compared with the proximity effect in the competition mechanism, the role of the learning mechanism is broader and can be extended to the whole country. Berry and Gray's research has shown that the diffusion speed of a policy innovation between regions is a function of the diffusion speed across the country [17]. The higher the proportion of cities adopting a policy across the country, the more likely the region is to implement the policy [17]. Research by domestic scholars has also shown that the learning mechanism, to some extent, leads to the diffusion of policy innovation. The adoption of the policy supports good development in the region, with policy adoption by the government promoted as a reference that supports its imitation.

Hypothesis 7 (H7). The higher the proportion of prefecture-level cities implementing the publicprivate partnership (PPP) policy nationwide, the more likely its adoption by a prefecture-level city.

News reports are today the most common information medium. They play an important role in the policy agenda and are an important method of political socialization. The "focus effect" of news reports is expectant with the huge pressure of public opinion which urges local governments to pay attention to public demand and achieve the goal of decision-making democratization [41-43]. Previous studies have shown that news reports play an important role in the policy diffusion of examples such as a public bicycle program [42,44], local government performance evaluation [37], and government purchase of public services $[43,45]$ and in other fields $[44,46]$.

Hypothesis 8 (H8). The more news reports published about the government and social capital cooperation policies in a particular year, the greater the likelihood of their adoption by a prefecturelevel city.

\section{Data and Methods}

\subsection{Sample Selection}

This study selects the Chinese mainland prefecture-level city as the basic analysis unit, with a time span of 2004-2020: the longest survival period of the observation object is 16 years. The study examines the adoption and diffusion of the PPP policy in Chinese mainland prefecture-level cities within this time span. When determining the policy's adoption time, the official documents issued by the local government are taken as the basis; the observation starting point is 2004, the observation end is the year of the policy's adoption, and data after the end year are eliminated. After data screening and sorting, the study investigated 282 prefecture-level cities and constructed 3,239 "city-year" observation points.

Prefecture-level cities are one of the administrative divisions in China and are under the jurisdiction of provinces and autonomous regions; they are one level higher than countylevel cities. This study selects prefecture-level cities as the basic analysis unit, mainly for the following three reasons: (1) compared to provincial administrative units, the sample 
size of prefecture-level cities is larger, with this better reflecting the law of policy innovation diffusion and the relationship between variables; (2) compared to administrative units at the county level, the sample size of prefecture-level cities is moderate, which is more practical in data collection and measurement analysis; and (3) taking the middle-level prefecture-level cities as the research object not only fully reflects the "top-down" diffusion influence of provincial capital cities and subprovincial cities, but also reflects the "bottomup" diffusion influence of county administrative units. Therefore, prefecture-level cities are more suitable as the analysis unit for investigating the diffusion of policy innovation. The dependent variable data of this study are derived from the compilation of government and social capital cooperation model policies and legal documents and from a policy search of the Peking University Law website, as well as from official channels, such as the Chinese government procurement website and local governments' official websites. The independent variable data come from the China Urban Statistical Yearbook, statistical bulletins of cities at all levels, and the China National Knowledge Infrastructure (CNKI) newspaper database.

\subsection{Model}

This study examines the diffusion of innovation in the PPP policy from 2004-2020 and seeks to build a theoretical framework to explain the motivation of local governments to adopt the policy. Specifically, it measures the influence of public service demand, level of economic development, government financial resources, city administrative level, higherlevel government pressure, proximity effect, national proportion of cities adopting the PPP policy, and news reports on the adoption of government and social capital cooperation policies by prefecture-level cities. To test the theoretical hypotheses, this study uses event history analysis (EHA) to verify the motivation for PPP policy adoption by these cities.

Event history analysis explains a qualitative change (an event) that occurs in an individual's behavior at a particular point in time [38]. Event history models focus on the timing of the first adoption. Event history analysis examines either the event timing (the event occurs sooner or later) or the overall probability of the ultimate event occurrence [37]. Event history analysis has been applied to both discrete-time events and continuous-time events. The strength of event history analysis is that researchers can pinpoint the direct impact of a policy change on the government [7]. The EHA method is used to study the event's manner and influencing factors, paying attention to the qualitative change of an event over a specific time span $[7,38,42]$. Compared to the inherent disadvantages of the ordinary least squares (OLS) estimation method in processing censored and diachronic data, EHA can more effectively solve these problems. The EHA method is used to measure the probability of the occurrence of the event at time $t$, based on the observation value of variables at time $t-1$. The combination analysis of longitudinal time series data and transverse section data is applicable for exploring the factors influencing the occurrence of the event [45]. As the dependent variable in this study is a binary variable, the study uses the binary logistic regression model for estimation when using EHA to identify the relationships between the variables. In this study, the data of the variables are recorded on a yearly basis. Therefore, a logistic regression model is selected to analyze the discrete-time series, with the following statistical models obtained after integrating the relevant variables:

$$
\operatorname{logit}\left(P_{i, t}\right)=\log \left(\frac{P_{i, t}}{1-P_{i, t}}\right)=\alpha+\beta X+\mu
$$

where $P_{i, t}$ is the probability that prefecture-level city government $i$ adopts the PPP policy at time $t, \alpha$ is the basic risk probability of diachronic data, $\beta$ is the regression coefficient of each independent variable, $X$ is the set of all arguments, and the constant term $\mu$ refers to the error. 


\subsection{Variables}

\subsubsection{Dependent Variable}

The study's dependent variable is the adoption of the PPP policy by a prefecture-level city, that is, the probability of prefecture-level city government $i$ adopting the cooperative policy of government and social capital at time $t$. The explained variable is a binary virtual variable. If the prefecture-level city government $i$ issued the relevant policies of government and social capital cooperation at time $t$, it is assigned a value of 1 , with a value of 0 assigned if these policies were issued the year before time $t$, while data for issuance after time $t$ are eliminated.

\subsubsection{Independent Variables}

Population size is the regulator of policy innovation diffusion and an important factor in policy innovation adoption. The population scale variable in this study is measured by the total population of a prefecture-level city at the end of the previous year. Due to the large size of this value, to reduce the risk of multicollinearity between variables, the natural logarithm is taken as the measurement value.

The level of social and economic development is a key factor in the diffusion of policy innovation [7]. The per capita GDP of a city is a key indicator reflecting the level of social and economic development of a region. In this study, the per capita GDP of a prefecture-level city is adopted to measure the level of local economic development. The per capita GDP of prefecture-level city government $i$ in $t-1$ year is selected, with the natural logarithm taken as the statistical value of this variable. To measure the financial resources of the prefecture-level municipal government, the per capita general budget income of the local finance is taken as the measurement index. The local general budget income of prefecture-level municipal government $i$ in $t-1$ year is selected and divided by the total population of the prefecture-level municipal government at the end of $t-1$ year, with the calculation results classified into the measurement model in the form of a logarithm. The city's administrative level is based on the administrative divisions announced by the Ministry of Civil Affairs, with the value assigned to provincial capital cities and subprovincial cities being 1 and the value assigned to other prefecture-level cities being 0 .

Policy innovation diffusion in China has a significant top-down compulsion. The higher-level government can use its authority to mandate the diffusion of policy innovation. The variable of pressure from higher-level government considers the influence of central government documents on the adoption of policies by prefecture-level municipal governments. In 2014, the Ministry of Finance established the government and social capital cooperation center. In the same year, the State Council, the National Development and Reform Commission, the Ministry of Finance, and other departments issued documents to regulate and guide cooperation between the government and social capital. In the current study, 2014 was taken as the dividing point, with the variable assigned a value of 1 for 2014 and later and a value of 0 for other years. The proximity effect is measured by the number of neighboring cities that have adopted the PPP policy in $t-1$. The national proportion of cities adopting the PPP policy is used to measure the impact of the learning mechanism on innovation adoption, with this obtained by dividing the number of cities adopting the policy in the whole country by the total number of prefecture-level cities in the whole country in $t-1$ year. The number of news reports reflects the impact of public opinion pressure on the diffusion of policy innovation. Based on the full-text database of CNKI's important newspapers, this study searched for the number of news reports from 2004-2020, using the search themes of "cooperation between government and social capital", "PPP", and "public utilities franchise", selecting the number of news reports in $t-1$ year, and bringing the data into the measurement model in logarithmic form. The explanation and data sources of the variables selected in this study are shown in Table 1. 
Table 1. Variable setting and data sources.

\begin{tabular}{|c|c|c|}
\hline Variables & Measures & Data Sources \\
\hline Adoption & $\begin{array}{l}1 \text { if the prefecture-level cities issue } \\
\text { PPP-related policies; otherwise, } 0 .\end{array}$ & $\begin{array}{l}\text { Compilation of PPP Policies and Legal } \\
\text { Documents, } \\
\text { Pkulaw.cn }\end{array}$ \\
\hline Population size * & $\begin{array}{l}\text { Total population of prefecture-level cities } \\
\text { at the end of the year }\end{array}$ & China Urban Statistical Yearbook \\
\hline Economic development level ${ }^{*}$ & GDP per capita & China Urban Statistical Yearbook \\
\hline Government financial resources * & $\begin{array}{l}\text { Per capita general budget income of local } \\
\text { finance, i.e., general budget income of } \\
\text { local finance/total population. }\end{array}$ & China Urban Statistical Yearbook \\
\hline City administrative level & $\begin{array}{l}1 \text { for provincial capital cities and } \\
\text { subprovincial cities, and } 0 \text { for ordinary } \\
\text { prefecture-level cities. }\end{array}$ & $\begin{array}{l}\text { Official website of the Ministry of Civil } \\
\text { Affairs of the People's Republic of China }\end{array}$ \\
\hline Superior government pressure & $\begin{array}{l}1 \text { if the central government issued } \\
\text { relevant documents; otherwise, } 0 \text {. }\end{array}$ & $\begin{array}{l}\text { Official website of PPP center of the Civil } \\
\text { Affairs Ministry }\end{array}$ \\
\hline Proximity effect & $\begin{array}{l}\text { The number of neighboring } \\
\text { prefecture-level cities adopting this policy } \\
\text { earlier than it. }\end{array}$ & Pkulaw.cn \\
\hline National proportion & $\begin{array}{l}\text { The number of prefecture cities that have } \\
\text { issued this policy nationwide divided by } \\
\text { the total number of prefecture-level cities. }\end{array}$ & Pkulaw.cn \\
\hline Number of news reports * & $\begin{array}{l}\text { Number of news reports on this topic } \\
\text { published in that year. }\end{array}$ & CNKI database \\
\hline
\end{tabular}

Note: Superscript asterisk * expresses the natural logarithm of the variable.

\subsection{Ethical Approval}

This study uses secondary statistical data from China Urban Statistical Yearbook following all ethical issues. Besides, it has been approved by the ethical committee of the School of Public Administration, Sichuan University, Chengdu, China.

\section{Results}

\subsection{Descriptive Statistics and Correlation Analysis}

In this study, the variance inflation factor (VIF) value is used to test multicollinearity between the variables. The larger the VIF value, the smaller the tolerance of explanatory variables, and the more collinearity. In this study, the VIF values of independent variables are far lower than the warning value of 10 , indicating that no serious collinearity exists between variables. The descriptive statistical results and correlation analysis results of the variables are shown in Tables 2 and 3, respectively. Preliminary analysis shows that the adoption of the dependent variable, PPP policy adoption, is weakly related to the independent variables population size, level of economic development, government financial resources, and city administrative level. The correlation coefficients between the dependent variable and independent variables, national proportion and news reports, are higher than 0.5 , which is significant at the 0.01 level, indicating that the above independent variables and dependent variable have moderate correlation, thus providing preliminary evidence supporting Hypotheses $\mathrm{H} 7$ and $\mathrm{H} 8$. 
Table 2. Descriptive statistics.

\begin{tabular}{cccccc}
\hline Variables & N & Min & Max & Mean & Std. Dev. \\
\hline Adoption & 3239 & 0.000 & 1.000 & 0.085 & 0.278 \\
\hline Population size & 3239 & 2.708 & 7.192 & 5.800 & 0.661 \\
\hline Economic development level & 3239 & 7.415 & 12.456 & 9.928 & 0.788 \\
\hline Government financial resources & 3239 & 3.969 & 10.260 & 7.031 & 1.090 \\
\hline City administrative level & 3239 & 0.000 & 1.000 & 0.069 & 0.253 \\
\hline Superior government pressure & 3239 & 0.000 & 1.000 & 0.216 & 0.412 \\
\hline Proximity effect & 3239 & 0.000 & 19.000 & 1.860 & 2.715 \\
\hline National proportion & 3239 & 0.000 & 0.952 & 0.128 & 0.182 \\
\hline Number of news reports & 3239 & 4.663 & 7.916 & 5.852 & 0.949 \\
\hline
\end{tabular}

Note: Std. Dev. = standard deviation.

Table 3. Correlation analysis.

\begin{tabular}{|c|c|c|c|c|c|c|c|c|c|}
\hline & ADOPT & POPU & ECO & FINANCE & LEVEL & PRES & PROX & NATIONPRO & NEWS \\
\hline ADOPT & 1.000 & & & & & & & & \\
\hline POPU & 0.031 & 1.000 & & & & & & & \\
\hline ECO & $0.245^{* *}$ & $-0.186^{* *}$ & 1.000 & & & & & & \\
\hline FINANCE & $0.252^{* *}$ & $-0.229^{* *}$ & $0.935^{* *}$ & 1.000 & & & & & \\
\hline LEVEL & $0.045 *$ & $0.156^{* *}$ & $0.156^{* *}$ & 0.210 ** & 1.000 & & & & \\
\hline PRES & $0.487^{* *}$ & 0.007 & $0.405^{* *}$ & $0.416^{* *}$ & $-0.056^{* *}$ & 1.000 & & & \\
\hline PROX & $0.455^{* *}$ & $0.096^{* *}$ & 0.362 ** & $0.331^{* *}$ & $-0.138^{* *}$ & $0.608^{* *}$ & 1.000 & & \\
\hline NATIONPRO & $0.578^{* *}$ & -0.004 & $0.361^{* *}$ & $0.344^{* *}$ & $-0.071^{* *}$ & $0.732 * *$ & $0.810^{* *}$ & 1.000 & \\
\hline NEWS & $0.531^{* *}$ & 0.002 & $0.178^{* *}$ & $0.187^{* *}$ & -0.031 & 0.842 ** & $0.584^{* *}$ & $0.743^{* *}$ & 1.000 \\
\hline
\end{tabular}

Notes: Superscript asterisks ${ }^{* *} p<0.01,{ }^{*} p<0.05$; ADOPT $=$ adoption, $\mathrm{POPU}=$ population size, $\mathrm{ECO}=$ economic devel opment level, FINANCE = government financial resources, LEVEL = city administrative level, PRES = superior government pressure, $\mathrm{PROX}=$ proximity effect, $\mathrm{NATIONPRO}=$ national proportion, $\mathrm{NEWS}=$ number of news reports.

\subsection{Model Analysis}

In accordance with the Hosmer-Lemeshow test [46], the significance of the regression model is far greater than the reference value of 0.05 , and the prediction percentage of the model is greater than $50 \%$, providing evidence that the binary logistic regression model established in this study is reasonable and can reflect the real relationship between variables. The EHA results, based on binary logistic regression, are shown in Table 4. Models 1, 2, and 3 are the results of regression analysis undertaken separately for motivation factors, resource/obstacle factors, and external factors, respectively. Models 4, 5, and 6 are the results of regression analysis after combination of the three types of variables. Model 7 is the all-factor model integrating the three types of variables. The statistical results report the odds ratio (OR) of each variable outside the brackets, with the standard error (SE) reported inside the brackets.

In addition, Table 4 reports the constant terms, chi-square values, degrees of freedom, pseudo R2 values, and other indicators reflecting the goodness of fit of each model. Among the seven models, the minimum value of pseudo R2 is 0.002 , while the highest value of pseudo R2 is 0.531 in the all-factor model, indicating that the model has a good fit and that the independent variables have a strong explanatory power on the dependent variable. 
Table 4. Event history analysis (EHA) of PPP policy diffusion.

\begin{tabular}{|c|c|c|c|c|c|c|c|}
\hline Variable & Model 1 & Model 2 & Model 3 & Model 4 & Model 5 & Model 6 & Model 7 \\
\hline $\begin{array}{c}\text { Population } \\
\text { size }\end{array}$ & $\begin{array}{l}1.191 * \\
(0.099)\end{array}$ & & & $\begin{array}{c}1.989^{* * *} \\
(0.112)\end{array}$ & $\begin{array}{l}1.390^{* *} \\
(0.130)\end{array}$ & & $\begin{array}{c}1.661^{* * *} \\
(0.149)\end{array}$ \\
\hline $\begin{array}{c}\text { Economic } \\
\text { development } \\
\text { level }\end{array}$ & & $\begin{array}{l}1.552^{*} \\
(0.238)\end{array}$ & & $\begin{array}{c}1.339 \\
(0.246)\end{array}$ & & $\begin{array}{c}0.948 \\
(0.275)\end{array}$ & $\begin{array}{c}0.941 \\
(0.279)\end{array}$ \\
\hline $\begin{array}{l}\text { Government } \\
\text { financial } \\
\text { resources }\end{array}$ & & $\begin{array}{c}1.892 * * * \\
(0.173)\end{array}$ & & $\begin{array}{c}2.523 * * * * \\
(0.184)\end{array}$ & & $\begin{array}{c}1.5575^{* *} \\
(0.208)\end{array}$ & $\begin{array}{c}1.888^{* * * *} \\
(0.217)\end{array}$ \\
\hline $\begin{array}{l}\text { City adminis- } \\
\text { trative } \\
\text { level }\end{array}$ & & $\begin{array}{c}1.082 \\
(0.225)\end{array}$ & & $\begin{array}{l}1.707^{* *} \\
(0.239)\end{array}$ & & $\begin{array}{c}0.226 * * * \\
(0.311)\end{array}$ & $\begin{array}{c}0.340^{* * * *} \\
(0.333)\end{array}$ \\
\hline $\begin{array}{l}\text { Superior } \\
\text { government } \\
\text { pressure }\end{array}$ & & & $\begin{array}{l}1.218 \\
(0.410)\end{array}$ & & $\begin{array}{c}1.226 \\
(0.411)\end{array}$ & $\begin{array}{c}0.740 \\
(0.459)\end{array}$ & $\begin{array}{c}0.586 \\
(0.469)\end{array}$ \\
\hline $\begin{array}{c}\text { Proximity } \\
\text { effect }\end{array}$ & & & $\begin{array}{c}0.986 \\
(0.031) \\
\end{array}$ & & $\begin{array}{c}0.964 \\
(0.032) \\
\end{array}$ & $\begin{array}{c}1.012 \\
(0.032) \\
\end{array}$ & $\begin{array}{c}0.975 \\
(0.033) \\
\end{array}$ \\
\hline $\begin{array}{l}\text { National } \\
\text { proportion }\end{array}$ & & & $\begin{array}{c}6.093 * * * \\
(1.807) \\
\end{array}$ & & $\begin{array}{l}8.516^{* * *} \\
(0.582)\end{array}$ & $6.109^{* * *}(0.568)$ & $\begin{array}{c}10.473^{* * *} \\
(0.591)\end{array}$ \\
\hline $\begin{array}{l}\text { Number of } \\
\text { news reports }\end{array}$ & & & $4.242 * * * * .205)$ & & $\begin{array}{l}4.206^{* * *} \\
(0.205)\end{array}$ & $\begin{array}{c}4.563 * * * \\
(0.209)\end{array}$ & $\begin{array}{c}4.581^{* * *} \\
(0.209)\end{array}$ \\
\hline Constant & $\begin{array}{c}0.033^{* * *} \\
(0.586)\end{array}$ & $\begin{array}{c}0.00008^{* * *} \\
(1.367)\end{array}$ & $\begin{array}{c}0.000004^{* * *} \\
(1.173)\end{array}$ & $\begin{array}{c}5.1502 \times 10^{-8 * * *} \\
(1.640)\end{array}$ & $\begin{array}{c}6.0398 \times 10^{-7} * * * \\
(1.402)\end{array}$ & $\begin{array}{c}6.3949 \times 10^{-7} * * * \\
(2.146)\end{array}$ & $\begin{array}{c}6.8449 \times 10^{-9} \text { *** } \\
(2.553)\end{array}$ \\
\hline Chi-square & $3.194 *$ & $22.495^{* * *}$ & $79.45^{* * *}$ & $26.219^{* * *}$ & $80.111^{* * *}$ & $84.786^{* * *}$ & 85.901 *** \\
\hline $\mathrm{df}$ & 1 & 3 & 4 & 4 & 5 & 7 & 8 \\
\hline Pseudo R2 & 0.002 & 0.15 & 0.495 & 0.177 & 0.499 & 0.524 & 0.531 \\
\hline $\mathrm{N}$ & 3239 & 3239 & 3239 & 3239 & 3239 & 3239 & 3239 \\
\hline
\end{tabular}

Among the motivation factor variables, population size and PPP policy adoption are significant at the 0.01 level in Models 4 and 7 and significant at the 0.05 level in Model 5 . The odds ratio (OR) in the four models is greater than 1, indicating that the independent variable, population size, has a positive impact on the dependent variable, so Hypothesis H1 is supported.

Among the resource/obstacle factor variables, the level of economic development has no significant influence on the dependent variable in Models 4, 6, and 7, while in the single regression model of resource/obstacle factors (Model 2), it has a significant influence on the dependent variable at the 0.1 level. The odds ratio (OR) is greater than 1 , indicating that the level of economic development has a positive role in promoting the adoption of government and social capital cooperation policies. In the correlation analysis, the level of economic development and the dependent variable are significantly positively correlated at the 0.01 level, so Hypothesis H2 is supported. In Model 6, government financial resources and the dependent variable are significantly correlated at the 0.05 level. In Models 2, 4, and 7 , the independent variable and dependent variable are significantly correlated at the 0.01 level, and in these four models, the odds ratio (OR) is greater than 1 . Combined with the results of the correlation analysis, the independent variable, government financial resources, and the dependent variable, PPP policy adoption, are significantly positively correlated at the 0.01 level, so Hypothesis $\mathrm{H} 3$ is supported. The independent variable, city administrative level, has no significant influence on the dependent variable in the resource/obstacle factor regression model (Model 2), with the odds ratio (OR) in Models 6 and 7 being less than 1 . Combined with the correlation analysis results, the correlation coefficient between the independent variable, city administrative level, and the dependent variable is 0.045 , which indicates weak, or no, correlation. Therefore, Hypothesis H4 is not supported.

Among the external factor variables, higher-level government pressure and proximity effect have no significant influence on the dependent variable in Models 3, 5, 6, and 7 . Meanwhile, in Models 6 and 7, the odds ratio (OR) of higher-level government pressure is less than 1, while the odds ratio (OR) of the independent variable, proximity effect, 
in Models 3, 5, and 7 is less than 1, so Hypotheses H5 and H6 cannot be supported. The independent variables, national proportion and news reports, are significant at the 0.01 level in the relevant models, while the odds ratio (OR) in each model is far greater than 1 , indicating that these two independent variables play a positive role in promoting the adoption of government and social capital policies. According to the correlation analysis results, the national proportion and news reports are significantly positively correlated with the dependent variable at the 0.01 level, while the correlation coefficients are greater than 0.4 , showing a moderate correlation. Therefore, hypotheses H7 and H8 about the learning mechanism and the imitation mechanism are supported (Table 4).

Population size plays a positive role in the adoption of PPP policy. Cities with large populations face more complex and diversified public service needs, and the government's response to these needs is more obvious. The current study's results are consistent with the findings of many Chinese [29,34] and foreign studies. Local governments' willingness is the basis for the implementation of innovation policies, while the pressure of public service demand arising from population size is an important driver for local governments to adopt innovation $[42,44]$.

As expected from the above results, the level of city economic development and government financial resources are important driving forces for the adoption of innovation policies, thus showing that the ability and willingness of local governments are complementary logical starting points that jointly affect the diffusion effect of innovation policies $[43,45]$. Cities with a higher level of economic development have higher tolerance for and openness to innovation policies [47]. This can provide a supportive environment for the implementation of innovation policies. This study finds that city administrative level has no effect on the adoption of the policy of cooperation between the government and social capital [48] and that the political factor does not play a key role in the process of its diffusion $[46,49]$.

Contrary to the study's expectation, the influence of higher-level government pressure on the dependent variable is not significant, which may be related either to the short time that has elapsed between central policy and city's policy implementation or to the variable measurement method. Hypothesis (H6) on the competition mechanism is not supported, but the effect of the learning mechanism on policy adoption is significant. In the all-factor model, the odds ratio (OR) of the learning mechanism is as high as 10.47. This indicates that, when other variables are fixed, the proportion of cities in China to adopt these policies will increase by one unit, and the probability of PPP policy adoption will increase by about 10 times. The number of news reports plays a significant role in policy adoption. For every unit of the logarithm of the number of news reports, the probability of policy adoption increases about 4 times. The "political firecracker" of the news media attracts the policy attention of local governments and has a real impact on the adoption of PPP policies.

\subsection{Robustness Test}

A robustness test is used to examine the study's research methods and the explanatory ability of the sample data [50]. When employing sample segmentation, variable replacement, and other methods to carry out repeatability experiments, if statistical results show that the symbols and significance have not changed, this proves that the statistical results are reliable [51]. This study tests the robustness of the research results from the following two main aspects: Firstly, based on the collected panel data, the study discusses population scale, level of economic development, government financial resources, city administrative level, higher-level government pressure, proximity effect in the province, the proportion of cities adopting the PPP policy in the province, and the influence of news reports on the dependent variable, PPP policy adoption, through regression analysis. Secondly, this study attempts to replace the independent variable, proximity effect, with the number of cities adopting the policy in the same province. The results of the two robustness tests are consistent with the above statistical results, further proving the reliability of the conclusions. 


\section{Conclusions}

Based on the panel data analysis of 282 prefecture-level cities in mainland China from 2004-2020, the current study established 3239 "city-year" observation points and constructed an analysis model of PPP policy adoption. The event history analysis (EHA) method has been used to carry out empirical analysis on the potential influencing factors. The results show that the size of city population, the level of city's economic development, government financial resources, the proportion of cities, and the number of news reports are the key factors influencing the adoption of PPP policy. The current study has reached a few conclusions.

Firstly, response to public demand is the key driver of government policy innovation. The ultimate concern of policy innovation is to solve social contradictions and meet public demand. In the process of PPP policy diffusion, symbolic implementation, selective implementation, fake PPP projects, and other phenomena seriously affect the quality and efficiency of policy implementation and easily lead to crises in public trust of administrative authorities. Establishing multiple channels to absorb society's public demands, breaking down communication barriers between the government and the public, and fully understanding public demands are the basic conditions for policy innovation diffusion and an effective government response.

Secondly, economic resources are important influencing factors for the adoption of innovation by local governments. At the same time, sufficient economic and financial resources are the material guarantee for the establishment of an early-stage platform for policy diffusion, effective allocation of resources in the middle stage, and sustainable supply in the later stage. A first pilot (trial) should be encouraged for policy innovation adoption in developed areas, leading to policy diffusion in less developed areas based on this policy implementation experience.

Thirdly, the learning mechanism has a positive impact on the diffusion of PPP policy. Over time, the PPP model has been continuously developed in many regions, with its substantive achievements verified by time, thus stimulating the learning enthusiasm of local governments and promoting policy diffusion. To promote the implementation of policy pilot (trial) work, enhance interaction between local governments, and realize the point-to-face diffusion of policy innovation, the experience and achievements of pilot (trial) work should not only be summarized in depth, but short-sighted behavior caused by blind competition should be avoided.

Finally, the atmosphere of public opinion created by news reports is another key driving force for the diffusion of PPP policy. The policy publicity and public opinion guidance of mainstream media are not only inducements for policy innovation and diffusion, but also provide a powerful guarantee.

The policy propaganda of mainstream media may become an obstacle to policy diffusion in some cases, often leading to a city successful in its policy practice being set up as a "political landscape", although this effect could also be removed by publicity. This effect has a restraining effect on policy diffusion and innovation from two aspects. Firstly, the city with a competitive relationship is more likely to deliberately avoid another city's successful experience, rather than continue to implement this successful experience in practice and in depth. Secondly, this "political landscape" would obtain more support with more finance, thus destroying its original policy field and not being conducive to the stability of its policy. The horizontal diffusion of experience is difficult to adjust flexibly in accordance with the specific situation of different cities.

The main limitation of this study is that only a few variables have been selected, with all potential factors yet to be covered. Potential factors could include political factors, promotion within the organization, and personal characteristics of government officials. In addition, the adoption of PPP policy innovation by local governments is a dynamic trial-and-error process. The index selection in future studies therefore should be optimized with the expansion of cases. 
Further research could be carried out on medium-term and long-term investigations on the diffusion process and the influence mechanism of policy innovation under the background of the administrative contract system of the Chinese government.

Author Contributions: Conceptualization, X.L.; methodology, X.L.; validation, X.L., Y.L., M.N.I.S. and X.Z.; data curation, X.L.; writing —original draft preparation, X.L.; writing - review and editing, X.L., Y.L., M.N.I.S. and X.Z. All authors have read and agreed to the published version of the manuscript.

Funding: This research received no external funding.

Institutional Review Board Statement: Not applicable.

Informed Consent Statement: Not applicable.

Data Availability Statement: Not applicable.

Conflicts of Interest: The authors declare no conflict of interest.

\section{Abbreviations}

CNKI China National Knowledge Infrastructure

DOI Diffusion of innovation

EHA Event history analysis

GDP Gross domestic product

PPP Public-private partnership

OLS Ordinary least squares

OR Odds ratio

SE Standard error

\section{References}

1. Wang, H.; Xiong, W.; Wu, G.; Zhu, D. Public-private partnership in Public Administration discipline: A literature review. Public Manag. Rev. 2018, 20, 293-316. [CrossRef]

2. Narasimhan, R.; Aundhe, M. Das Explanation of Public Private Partnership (PPP) Outcomes in E-Government-A Social Capital Perspective. In Proceedings of the 47th Hawaii International Conference on System Sciences, Waikoloa, HI, USA, 6-9 January 2014; IEEE: Piscataway, NJ, USA, 2014; pp. 2189-2199.

3. Savas, E.S. Privatization and Public-Private Partnerships; Chatham House: New York, NY, USA, 2000; ISBN 9781566430739.

4. Li, Y.; Wang, X.; Westlund, H.; Liu, Y. Physical Capital, Human Capital, and Social Capital: The Changing Roles in China's Economic Growth. Growth Chang. 2015, 46, 133-149. [CrossRef]

5. Wang, C.; $\mathrm{Xu}, \mathrm{L}$. The relationship between PPP and government franchise and its legislative strategy. Financ. Res. 2016, 6, 78-85.

6. Yang, X. The relationship between franchise and PPP: Based on the background of developed countries. Financ. Sci. 2016, 6, 61-71.

7. Xufeng, Z.; Hui, Z. Social Policy Diffusion from the Perspective of Intergovernmental Relations: An Empirical Study of the Urban Subsistence Allowance System in China (1993-1999). Soc. Sci. China 2018, 39, 78-97. [CrossRef]

8. Mintrom, M.; Vergari, S. Policy Networks and Innovation Diffusion: The Case of State Education Reforms. J. Polit. 2015, 60, 126-148. [CrossRef]

9. Gilardi, F.; Wasserfallen, F. Policy Diffusion: Mechanisms and Practical Implications. In Proceedings of the Governance Design Network (GDN) Workshop, National University of Singapore, Singapore, 17-18 February 2017; pp. 1-21.

10. Parkes, S.D.; Marsden, G.; Shaheen, S.A.; Cohen, A.P. Understanding the diffusion of public bikesharing systems: Evidence from Europe and North America. J. Transp. Geogr. 2013, 31, 94-103. [CrossRef]

11. Delmon, J. Public-Private Partnership Projects in Infrastructure; Cambridge University Press: Cambridge, UK, 2010; ISBN 9780511974403.

12. Butler, D.M.; Volden, C.; Dynes, A.M.; Shor, B. Ideology, Learning, and Policy Diffusion: Experimental Evidence. Am. J. Pol. Sci. 2017, 61, 37-49. [CrossRef]

13. Cheng, Z.; Wang, H.; Xiong, W.; Zhu, D.; Cheng, L. Public-private partnership as a driver of sustainable development: Toward a conceptual framework of sustainability-oriented PPP. Environ. Dev. Sustain. 2021, 23, 1043-1063. [CrossRef]

14. Cheng, Z.; Wang, H.; Song, J. Is space important to PPP: An exploration of spatial governance mechanism of PPP in China. Regul. Rev. 2018, 1, 102-115.

15. Walker, J.L. The Diffusion of Innovations among the American States. Am. Polit. Sci. Rev. 1969, 63, 880-899. [CrossRef]

16. Berry, F.S.; Berry, W.D. State Lottery Adoptions as Policy Innovations: An Event History Analysis. Am. Polit. Sci. Rev. 1990, 84, 395-415. [CrossRef]

17. Gray, V. Innovation in the States: A Diffusion Study. Am. Political Sci. Rev. 1973, 67, 1174-1185. [CrossRef] 
18. Mohr, L.B. Determinants of Innovation in Organizations. Am. Polit. Sci. Rev. 1969, 63, 111. [CrossRef]

19. Rogers, E.M. Diffusion of Innovation, 3rd ed.; The Free Press: New York, NY, USA, 1983; pp. 1-236.

20. Williams, N.; Huggins, R.; Thompson, P. Social Capital and Entrepreneurship: Does the Relationship Hold in Deprived Urban Neighbourhoods? Growth Chang. 2017, 48, 719-743. [CrossRef]

21. Weible, C.M.; Sabatier, P.A. Theories of the Policy Process; Routledge: New York, NY, USA, 2017.

22. Haapanen, M.; Lenihan, H.; Tokila, A. Innovation Expectations and Patenting in Private and Public R\&D Projects. Growth Chang. 2017, 48, 744-768. [CrossRef]

23. Verma, M.; Priyadarshee, A. Improving Service Delivery through State-Citizen Partnership: The Case of the Ahmedabad Urban Transport System. Growth Chang. 2015, 46, 321-336. [CrossRef]

24. Parra-requena, G.; Molina-morales, F.X.; García-villaverde, P.M. The Mediating Effect of Cognitive Social Capital on Knowledge Acquisition in Clustered Firms. Growth Chang. 2010, 41, 59-84. [CrossRef]

25. Jae Moon, M.; DeLeon, P. Municipal Reinvention: Managerial Values and Diffusion among Municipalities. J. Public Adm. Res. Theory 2001, 11, 327-351. [CrossRef]

26. Wejnert, B. Integrating models of diffusion of innovations: A conceptual framework. Annu. Rev. Sociol. 2002, 28, 297-326. [CrossRef]

27. Shipan, C.R.; Volden, C. The Mechanisms of Policy Diffusion. Am. J. Pol. Sci. 2008, 52, 840-857. [CrossRef]

28. Bouché, V.; Volden, C. Privatization and the diffusion of innovations. J. Polit. 2011, 73, 428-442. [CrossRef]

29. Deep, A.; Kim, J.; Less, M. Realizing the Potential of Public-Private Partnerships to Advance Asia's Infrastructure Development; Deep, A., Kim, J., Lee, M., Eds.; Asian Development Bank: Manila, Philippines, 2019.

30. Easton, D. An Approach to the Analysis of political Systems. World Polit. 1957, 9, 383-400. [CrossRef]

31. Zheng, G.; Zhu, L.; Liu, C.; Chen, Y. TMT social capital, network position and innovation: The nature of micro-macro links. Front. Bus. Res. China 2019, 13, 3. [CrossRef]

32. Zhu, X. Mandate Versus Championship: Vertical government intervention and diffusion of innovation in public services in authoritarian China. Public Manag. Rev. 2014, 16, 117-139. [CrossRef]

33. Tolbert, C.J.; Mossberger, K.; McNeal, R. Institutions, policy innovation, and e-government in the American States. Public Adm. Rev. 2008, 68, 549-563. [CrossRef]

34. Murphy, L.J.; Pickernell, D.; Thiomas, B.; Fuller, D. Innovation, social capital and regional policy: The case of the communities first programme in wales. Reg. Stud. Reg. Sci. 2018, 5, 21-39. [CrossRef]

35. Habisch, A.; Adaui, C.R.L. A Social Capital Approach Towards Social Innovation. In Social Innovation; Osburg, T., Schmidpeter, R., Eds.; Springer: Berlin/Heidelberg, Germany, 2013; pp. 65-74. ISBN 978-3-642-36539-3.

36. Zhou, X. The Institutional Logic of Collusion among Local Governments in China. Mod. China 2010, 36, 47-78. [CrossRef]

37. Wu, J.; Zhang, P. Local government innovation diffusion in China: An event history analysis of a performance-based reform programme. Int. Rev. Adm. Sci. 2018, 84, 63-81. [CrossRef]

38. Zhang, Y.; Zhu, X. Multiple mechanisms of policy diffusion in China. Public Manag. Rev. 2019, 21, 495-514. [CrossRef]

39. Leisering, L.; Liu, T.; ten Brink, T. Synthesizing disparate ideas: How a Chinese model of social assistance was forged. Glob. Soc. Policy 2017, 17, 307-327. [CrossRef]

40. Warsen, R.; Greve, C.; Klijn, E.H.; Koppenjan, J.F.M.; Siemiatycki, M. How do professionals perceive the governance of publicprivate partnerships? Evidence from Canada, the Netherlands and Denmark. Public Adm. 2020, 98, 124-139. [CrossRef]

41. Zhang, L.; Zhao, Z.; Kan, Z. Private-sector partner selection for public-private partnership projects of electric vehicle charging infrastructure. Energy Sci. Eng. 2019, 7, 1469-1484. [CrossRef]

42. Zhang, H.; Shaheen, S.A.; Chen, X. Bicycle Evolution in China: From the 1900s to the Present. Int. J. Sustain. Transp. 2014, 8 , 317-335. [CrossRef]

43. Li, B.; Akintoye, A.; Edwards, P.J.; Hardcastle, C. Critical success factors for PPP/PFI projects in the UK construction industry. Constr. Manag. Econ. 2005, 23, 459-471. [CrossRef]

44. Yang, J.; Song, L.; Xing, Z. Credit Default of Local Public Sectors in Chinese Government-Pay PPP Projects: Evidence from Ecological Construction. Adv. Civ. Eng. 2019, 2019, 2138525. [CrossRef]

45. Allison, P.D. Event History and Survival Analysis, 2nd ed.; SAGE Publications, Inc.: Thousand Oaks, CA, USA, 2014.

46. Hosmer, D.W.; Lemeshow, S. Applied Logistic Regression, 2nd ed.; Wiley: Hoboken, NJ, USA, 2000; pp. 1-373. ISBN 0-471-35632-8.

47. Cheevapattananuwong, P.; Baldwin, C.; Lathouras, A.; Ike, N. Social capital in community organizing for land protection and food security. Land 2020, 9, 69. [CrossRef]

48. Liu, Z.; Wei, Y.; Li, Q.; Lan, J. The mediating role of social capital in digital information technology poverty reduction an empirical study in urban and rural china. Land 2021, 10, 634. [CrossRef]

49. Yang, H.; Huang, K.; Deng, X.; Xu, D. Livelihood capital and land transfer of different types of farmers: Evidence from panel data in sichuan province, china. Land 2021, 10, 532. [CrossRef]

50. Zhang, Y. From State to Market: Private Participation in China's Urban Infrastructure Sectors, 1992-2008. World Dev. 2014, 64, 473-486. [CrossRef]

51. Batra, R. Gauging the stakeholders' perspective: Towards PPP in building sectors and housing. J. Hous. Built Environ. 2020, 35, 1123-1156. [CrossRef] 